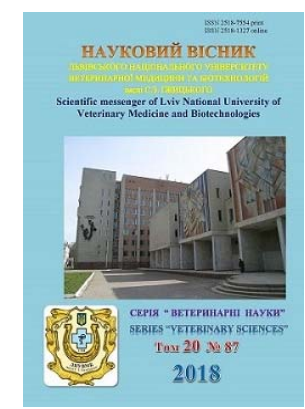

\author{
Науковий вісник Дьвівського національного університету \\ ветеринарної медицини та біотехнологій імені С.З. Гжицького
}

\author{
Scientific Messenger of Lviv National University \\ of Veterinary Medicine and Biotechnologies
}

\title{
Biofilm-forming ability of coccus forms of the caecal microflora of laying hens when using the probiotic and nanonutrition cobalt
}

\author{
Ia. Turko, V. Ushkalov
}

Stepan Gzhytskyi National University of Veterinary Medicine and Biotechnologies Lviv, Ukraine

Article info

Received 05.02.2018

Received in revised form 19.03.2018

Accepted 23.03.2018

Stepan Gzhytskyi National University of Veterinary Medicine and Biotechnologies Lviv, Pekarska str., 50, Lviv, 79010, Ukraine. Tel.: +38-097-348-31-45 E-mail:turko07@ukr.net
Turko, Ia., \& Ushkalov, V. (2018). Biofilm-forming ability of coccus forms of the caecal microflora of laying hens when using the probiotic and nanonutrition cobalt. Scientific Messenger of Lviv National University of Veterinary Medicine and Biotechnologies. 20(87), 60-64. doi: $10.15421 /$ nvlvet8712

The use of the feed supplement on the basis of probiotic microorganisms of the genus Lactobacillus in combination with nano-cobalt preparations in a dose of $0.08 \mathrm{mg} / \mathrm{kg}$ liveweight in laying hens caused the most significant reduction in the proportion of cow's forms of the microflora of the colon (Staphylococcus spp., Enterococcus spp., Streptococcus spp.) that formed high-density biofilms by increasing the percentage of these microorganisms with low and medium biofilm-forming ability. After 14 days of use of probiotic and nanocobalt at a dose of $0.08 \mathrm{mg} / \mathrm{kg}$, an increase in the percentage of Staphylococcus spp. microorganisms, which formed low and medium density biofilms, respectively, was 7.2 and $18.2 \%$, due to the reduction of those with high biofilm formation ability. Such a redistribution of the ability of the studied microorganisms to form a biofilm remained after 28 days of the experiment. However, the number of microorganisms of Staphylococcus spp., which formed low density biofilms, was maximum i.e. 46.2\%. Instead, the number of microorganisms of Staphylococcus spp., which formed high density biofilms, was minimal and amounted to $12.6 \%$. The indicated trend persists after the end of application of the additive after 14 days. When using probiotic and nano-cobalt at a dose of $0.08 \mathrm{mg} / \mathrm{kg}$, the highest reliability $(P<0.001)$ of changes in the biofilm-forming ability of microorganisms Enterococcus spp. was established, namely, its reduction. At the same time, the percentage of microorganisms that formed low-density biofilms was the highest in 28 days of use (by 5.1\%) and 14 days after the end of feeding of the additive (by 7.1\%). At the same time, the percentage of microorganisms Enterococcus spp. with a high biofilm-forming ability gradually decreased and reached a minimum of 28 days of the experiment (5.6\%). On the 14th day after stopping the feeding of the supplement, it reached $9.8 \%$. With an increase in the dose of nanocobalt up to $0.8 \mathrm{mg} / \mathrm{kg}$, significant changes were observed only on the 28th day of feeding and 14 days after the end of the feeding of the feed additive, namely: a decrease in the number of microorganisms Enterococcus spp. with a high biofilm production capacity of $3.4 \%$ and $4.8 \%$, respectively. Regarding microorganisms of Streptococcus spp. the most visible effect could be observed with the use of probiotic in a complex with nano-cobalt in a dose of $0.08 \mathrm{mg} / \mathrm{kg}$, namely: by $17.4 \%$, the number of microorganisms with high bio-plating ability with a gradual increase in the percentage of those that had a low (10.2\%) and average (by $7.2 \%)$ biofilm capacity. After the application of the suppressant was discontinued for 14 days, the corrected changes were maintained.

Key words: laying hens, cecum, nanocobalt, probiotic, biofilm, Staphylococcus spp., Enterococcus spp., Streptococcus spp.

\section{Біоплівкоутворююча здатність кокових форм мікрофлори сліпої кишки курей-несучок при застосуванні пробіотика та нанонутріцевтика кобальту}

\author{
Я.І. Турко, В.О. Ушкалов
}

Львівський національний університет ветеринарної медицини та біотехнологій імені С.3. Гжицького, м. Львів, Україна

Використання кормової добавки на основі пробіотичних мікроорганізмів роду Lactobacillus в комплексі з препаратами нанокобальту у дозі 0,08 мг/кг живої ваги в годівлі курей-несучок обумовило найбільш суттєве вірогідне зменшення частки кокових форм 
мікрофлори сліпих кишок (Staphylococcus spp., Enterococcus spp., Streptococcus spp.), щуо утворювали біоплівки високої щільності за рахунок збільшення відсотка цих мікроорганізмів з низькою та середньою біоплівкоутворюючою здатністю. Так, через 14 діб застосування пробіотика та нанокобальту у дозі 0,08 мг/кг встановлено зростання відсотка мікроорганізмів Staphyloсоссиs spр., щчо утворювали біоплівки низької і середньої щільності відповідно на 7,2 та 18,2\%, за рахунок зменшення таких з високою біоплівкоутворюючою здатністю. Такий перерозподіл здатності досліджуваних мікроорганізмів утворювати біоплівки зберігся і після 28 днів досліду. Проте, кількість мікроорганізмів Staphyloсоссиs sрр., щуо утворювали біоплівки низької шільності була максимальною і становила 46,2\%. Натомість, кількість мікроорганізмів Staphylococcus spр., щзо утворювали біоплівки високої щільності була мінімальною і становила 12,6\%. Вказана тенденція зберігається і після припинення застосування добавки через 14 діб. При використанні пробіотика та нанокобальту дозі 0,08 мг/кг встановлено найвищу достовірність (P < 0,001) змін у біоплівкоутворюючій здатності мікроорганізмів Еntеrососсиs spр., а саме: ї̈ зменшення. При цзьому зростання відсотка мікроорганізмів, изо утворювали низькошільні біоплівки, було найвищим через 28 днів застосування (на 5,1\%) та через 14 днів після припинення згодовування добавки (на 7,1\%). Водночас відсоток мікроорганізмами Enterocoсcиs spр. з високою біоплівкоутворюючою здатністю поступово зменшувався і сягав мінімума на 28 день досліду (5,6\%). На 14 день після припинення згодовування добавки він сягав 9,8\%. Із збільшенням дози нанокобальту до 0,8 мг/кг достовірні зміни були встановлені лише на 28 день згодовування та 14 день після завершення згодовування кормової добавки, а саме: встановлено зменшення кількості мікроорганізмів Enterocoсcиs spр. $з$ високою біоплівкоутворюючою здатністю відповідно на 3,4 і 4,8\%. Що стосується мікроорганізмів Strерtососсиs spр. то найбільш виражену дію можна було спостерігати при застосуванні пробіотика в комплексі з нанокобальтом у дозі 0,08 мг/кг, а саме: на 17,4\% зменшилась кількість мікроорганізмів з високою біоплівкоутворюючою здатністю з поступовим збільшенням відсотка таких, що мали низьку (на 10,2\%) та середню (на 7,2\%) біоплівкоутворюючу здатність. Після припинення застосування добавки на 14 день встановлені зміни співвідношення зберігались.

Ключові слова: кури-несучки, сліпа кишка, нанокобальт, пробіотик, біоплівки, Staphylococcus spp., Enterococcus spp., Streptococcus spp.

\section{Ветуп}

Нормальну мікрофлору організму птиці, яку пов'язують із іiі здоров'ям, умовно поділяють на дві групи: облігатну (постійну, автохтонну, індигенну) i факультативну (транзиторну) (Pavlova et al., 2006). Нормальна мікрофлора має елементи саморегуляції і в певних межах здатна протистояти впливу шкідливих умов, зберігаючи чисельність мікробних популяцій. При зниженій кількості облігатної мікрофлори або регресі їі захисних властивостей факультативна мікрофлора виявляє патогенні властивості (Scupham, 2007; Vecherskii et al., 2014).

Основну частину облігатної мікробної популяції складають біфідобактерії, анаеробні коки, бактероїди, клостридії та інші. Доведено, що облігатна мікрофлора становить 98-99\% (Round and Mazmanian, 2009). Основні групи облігатної мікрофлори можуть існувати як у просвіті кишечника, так і утворювати колонії на поверхні ентероцитів, тісно зв'язуючись з рецепторами епітелію у глікокаліксі (Scupham, 2009; Lukovs'ka, 2015). До складу облігатної мікрофлори може включатись і умовно-патогенна мікрофлора, видовий склад якої залежить від зовнішніх і внутрішніх чинників. Заселяючи спочатку макроорганізм, мікроорганізми перебувають у симбіотичному зв'язку з ним, створюючи на певний час імунологічну рівновагу (Lee and Mazmanian, 2010). Вагому частину мікрофлори товстого кишечнику птиці становлять бактероїди - анаеробні неспороутворюючі мікроорганізми, які беруть участь у процесах травлення, декон'югації жовчних кислот, утилізують полісахариди, а також ентерококи та стрептококи, кількість яких не перевищує кількості кишкової палички (Stanley et al., 2014).

Створена цими мікроорганізмами біоплівка на поверхні стінок кишечнику птиці захищає від транслокації бактерій у внутрішні органи та кров. Крім того, мікрофлора кишечнику стимулює дозрівання моноцитарно-макрофагально системи (Mohd Shaufi et al., 2015). При цьому колонізаційна резистентність, адгезивна здатність та міжмікробний антагонізм визначає конкурентоспроможність облігатної мікрофлори кишечнику (Dibner et al., 2008).

Факультативна мікрофлора здорової птиці в основному міститься в порожнині кишечнику і представлена умовно-патогенними стафілококами, стрептококами, гемолізуючими кишковими паличками, протеєм та грибками. Співвідношення між анаеробами та аеробами в травному каналі птиці дорівнює 10:1, а їхня біомаса відрізняється в 1000 разів. При зниженні імунітету птиці, стресі, інфекційних процесах, травмах, несприятливому харчуванні факультативна мікрофлора активно розмножується і викликає клінічні прояви кишкової інфекції (Baldi et al., 2009; Kamins'ka et al., 2015).

Таким чином, наведені вище основні функції мікрофлори шлунково-кишкового тракту птиці вказують про надзвичайно важливу роль мікробоценозу кишечнику у забезпеченні житєдіяльності птиці, підтриманні іiі здоров'я та високої продуктивності.

Саме тому метою наших досліджень було встановлення біоплівкоутворюючої здатності кокових форм мікрофлори сліпої кишки курей-несучок при застосуванні пробіотика та нанонутріцевтика кобальту.

\section{Матеріал і методи досліджень}

В експерименті використовували курей-несучок промислового поголів'я кросу Хайсекс браун м'ясояєчного напряму продуктивності масою 1400-1700 г. Кури контрольної групи отримували повнораціонний комбікорм. Кури дослідних груп (I-IV) отримували 3 водою Пробіотик на основі мікроорганізмів роду Lactobacillus відповідно до рекомендацій щодо застосування $\left(1,0 \mathrm{~cm}^{3} /\right.$ дм$\left.^{3}\right)$, а також добавки до комбікорму (II-IV): курям II дослідної групи до комбікорму додавали кобальту хлорид у дозі 0,08 мг/кг маси тіла (1,0 мг/кг корму), курям III i IV дослідних груп у комбікорм додавали наночастки Кобальту відповідно у дозі 0,08 мг/кг маси тіла та 0,8 мг/кг маси тіла.

Дослідження вмісту сліпих кишок проводили до задавання препаратів, через 14, 28 діб після початку 
та через 14 діб після закінчення задавання препаратів шляхом виділення мікроорганізмів Staphylococcus spp., Streptococcus spp., Enterococcus spp. та встановлення їх здатності утворювати біоплівки низької (менше ніж 0,5 од.опт.щ.), середньої (0,5-1,0 од.опт.щ.) та високої щільності (більше ніж 1,0 од.опт.щ.) in vitro (Kukhtyn et al., 2017).

\section{Результати та їх обговорення}

В результаті досліджень встановлено (табл. 1), що 14-денне застосування лише пробіотика в годівлі курей-несучок сприяло вірогідному зростанню відсотка мікроорганізмів Staphylococcus spp., що утворювали біоплівки низької щільності на 6,0\%. Водночас на 28 добу досліду зміни співвідношення мікроорганізмів, що утворювали різну щільність біоплівок були більш суттєвими. Так, кількість мікроорганізмів Staphylococcus spp. 3 низькою біоплівкоутворюючою здатністю продовжувала зростати до 48,4\% $(\mathrm{P}<0,001)$. Це вплинуло на зменшення відсотка цієї групи мікроорганізмів 3 високою та середньою біоплівкоутворюючою здатністю відповідно на 10,2 та $5,9 \%(\mathrm{P}<0,01)$.

\section{Таблиця 1}

Здатність Staphylococcus spp., виділених із вмісту сліпої кишки курей-несучок, до формування біоплівки різної щільності за умов впливу добавок Кобальту та Пробіотику у динаміці 42 діб (\%, n = 9)

\begin{tabular}{|c|c|c|c|c|c|}
\hline \multicolumn{2}{|c|}{ Терміни } & \multirow{2}{*}{$\begin{array}{c}\text { I } \\
\text { до згодовування }\end{array}$} & \multirow{3}{*}{$\begin{array}{c}\text { II } \\
14 \text { діб згодовування } \\
34,2 \pm 1,2\end{array}$} & \multirow{3}{*}{$\begin{array}{c}\text { III } \\
28 \text { діб згодовування } \\
36,2 \pm 1,5\end{array}$} & \multirow{3}{*}{$\begin{array}{c}\begin{array}{c}\text { IV } \\
14 \text { діб після припи- } \\
\text { нення згодовування }\end{array} \\
35,3 \pm 1,4\end{array}$} \\
\hline Групи & & & & & \\
\hline контроль & $\mathrm{H}$ & $32,9 \pm 1,3$ & & & \\
\hline & $\mathrm{C}$ & $29,1 \pm 1,1$ & $30,2 \pm 1,2$ & $31,6 \pm 1,3$ & $29,3 \pm 1,0$ \\
\hline & B & $38,0 \pm 1,5$ & $35,6 \pm 1,3$ & $32,1 \pm 1,4$ & $35,4 \pm 1,4$ \\
\hline I дослід & $\mathrm{H}$ & $32,3 \pm 1,8$ & $38,3 \pm 1,5^{* *}$ & $48,4 \pm 2,6^{* * *}$ & $41,4 \pm 2,5^{* *}$ \\
\hline \multirow[t]{2}{*}{ ПБ } & $\mathrm{C}$ & $27,3 \pm 1,3$ & $26,2 \pm 1,4$ & $21,4 \pm 1,1 * *$ & $28,4 \pm 1,3$ \\
\hline & $\mathrm{B}$ & $40,4 \pm 2,3$ & $35,5 \pm 1,9$ & $30,2 \pm 1,3 * *$ & $30,2 \pm 1,4 * *$ \\
\hline II дослід ПБ + & $\mathrm{H}$ & $32,3 \pm 1,4$ & $37,4 \pm 1,7$ & $44,0 \pm 1,6^{* * *}$ & $43,0 \pm 2,0 * * *$ \\
\hline $\mathrm{CoCl}_{2}$ у дозі & $\mathrm{C}$ & $26,2 \pm 1,2$ & $27,4 \pm 1,3$ & $27,5 \pm 1,3$ & $27,4 \pm 1,0$ \\
\hline 0,08 мг/кг & $\mathrm{B}$ & $41,5 \pm 2,5$ & $35,2 \pm 1,7$ & $28,5 \pm 1,1 * * *$ & $29,6 \pm 1,5 * * *$ \\
\hline III дослід & $\mathrm{H}$ & $31,1 \pm 1,2$ & $38,3 \pm 1,5^{* *}$ & $46,2 \pm 1,6^{* * *}$ & $46,1 \pm 1,8^{* * *}$ \\
\hline ПБ + НчСо у & $\mathrm{C}$ & $30,1 \pm 1,5$ & $48,3 \pm 1,8^{* * *}$ & $41,2 \pm 1,5 * * *$ & $39,4 \pm 1,4 * * *$ \\
\hline дозі 0,08 мг/кг & $\mathrm{B}$ & $38,8 \pm 1,3$ & $13,4 \pm 1,9 * * *$ & $12,6 \pm 1,8^{* * *}$ & $14,5 \pm 1,7^{* * *}$ \\
\hline IV дослід & $\mathrm{H}$ & $30,8 \pm 1,5$ & $29,0 \pm 1,1$ & $43,4 \pm 2,2 * * *$ & $45,3 \pm 2,6^{* * *}$ \\
\hline ПБ + НчСо у & $\mathrm{C}$ & $29,2 \pm 1,2$ & $47,4 \pm 2,5^{* * *}$ & $36,3 \pm 1,7 * *$ & $34,3 \pm 1,5^{*}$ \\
\hline дозі 0,8 мг/кг & $\mathrm{B}$ & $40,0 \pm 1,9$ & $23,6 \pm 1,1 * * *$ & $20,3 \pm 1,0 * * *$ & $20,4 \pm 1,5 * * *$ \\
\hline
\end{tabular}

В подальшому після припинення застосування пробіотика на 14 добу змін у кількості мікроорганізмів Staphylococcus spp. не було встановлено. Проте спостерігали перерозподіл між мікроорганізмами 3 малою та середньою біоплівкоутворюючою здатністю в бік зростання відсотка останніх. Варто зауважити, що відсоток мікроорганізмів Staphylococcus spp. 3 середньою біоплівкоутворюючою здатністю був майже на рівні контролю.

Очевидно, зменшення здатності мікроорганізмів Staphylococcus spp. до утворення біоплівок в цьому експерименті пояснюється пробіотичною дією мікроорганізмів роду Lactobacillus, що використовувались як кормова добавка та зменшенням здатності стафілококів адсорбуватись на ентероцитах та утворювати біоплівки, попереджуючи тим самим патогенну дію цих мікроорганізмів.

Подібна динаміка спостерігалась і при комплексному застосуванні пробіотика та $\mathrm{CoCl}_{2}$ у дозі 0,08 мг/кг за винятком мікроорганізмів Staphylococcus spp. 3 середньою біоплівкоутворюючою здатністю, рівень яких вірогідно не змінювався у всі періоди досліду.

Найбільш суттєвими були зміни при застосуванні пробіотика та наночасток кобальту в усіх досліджуваних дозових діапазонах. Через 14 діб застосування пробіотика та нанокобальту в дозі 0,08 мг/кг встанов- лено зростання відсотка мікроорганізмів Staphylococcus spp., що утворювали біоплівки низької і середньої щільності відповідно на 7,2 та $18,2 \%$ за рахунок зменшення таких з високою біоплівкоутворюючою здатністю. Такий перерозподіл здатності досліджуваних мікроорганізмів утворювати біоплівки зберігся і після 28 днів досліду. Проте кількість мікроорганізмів Staphylococcus spp., що утворювали біоплівки низької щільності, була максимальною і становила 46,2\%. Натомість кількість мікроорганізмів Staphylococcus $s p p$., що утворювали біоплівки високої щільності була мінімальною і становила $12,6 \%$.

Отже, застосування нанокобальту покращує резистентність слизової кишечника до колонізації ï потенційно патогенною групою мікроорганізмів Staphylococcus spp., що проявляється зниженням здатності цих мікроорганізмів до утворення біоплівок.

Варто відмітити, що вказана тенденція зберігається і після припинення застосування добавки через 14 діб.

Подібна динаміка співвідношення мікроорганізмів Staphylococcus spp. 3 різною біоплівкоутворюючою здатністю спостерігалась при застосуванні пробіотика та нанокобальту в дозі 0,8 мг/кг. Особливо це стосувалось мікроорганізмів, що утворювали біоплівки високої щільності, відсоток яких був вищий на 10,2$5,9 \%$ у різні часові діапазони досліду. Очевидно, це 
пояснюється токсичною дією нанокобальту в дозі $0,8 \mathrm{мг} /$ кг на організм, а отже і зменшенням резистентності кишечника до колонізації мікроорганізмами цієї групи.

Менш вираженими були зміни у динаміці співвідношення мікроорганізмів Enterococcus spp. 3 різною біоплівкоутворюючою здатністю при застосуванні пробіотика (табл. 2). Лише на 28 день досліду відбувся перерозподіл мікроорганізмами з високою і низькою здатністю до утворення біоплівок на користь останніх (Р <0,05). Подібні зміни зберігалися і протягом 14 днів після припинення застосування пробіотика.

Додавання до пробіотика $\mathrm{CoCl}_{2}$ у дозі 0,08 мг/кг практично не вплинуло на здатність до утворення біоплівок мікроорганізмами Enterococcus spp.

Проте у III досліді (ПБ + НчСо у дозі 0,08 мг/кг) встановлено найвищу достовірність $(\mathrm{P}<0,001)$ змін у біоплівкоутворюючій здатності мікроорганізмів, а саме: ii зменшення. При цьому зростання відсотка мікроорганізмами Enterococcus spp, що утворювали низькощільні біоплівки, було найвищим через 28 днів застосування (на 5,1\%) та через 14 днів після припинення згодовування добавки (на 7,1\%). Водночас відсоток мікроорганізмами Enterococcus spp. 3 високою біоплівкоутворюючою здатністю поступово зменшувався і сягав мінімума на 28 день досліду (5,6\%). На 14 день після припинення згодовування пробіотика в комплексі з нанокобальтом в дозі 0,08 мг/кг він сягав $9,8 \%$.

Iз збільшенням дози нанокобальту до 0,8 мг/кг (IV дослід) достовірні зміни були встановлені лише на 28 день згодовування та 14 день після завершення згодовування кормової добавки, а саме: встановлено зменшення кількості мікроорганізмів Enterococcus spp. 3 високою біоплівкоутворюючою здатністю відповідно на 3,4 і 4,8\%.

\section{Таблиця 2}

Здатність Enterococcus spp., виділених із вмісту сліпої кишки курей-несучок, до формування біоплівки різної щільності за умов впливу добавок Кобальту та Пробіотика у динаміці 42 діб (\%, n =9)

\begin{tabular}{|c|c|c|c|c|c|}
\hline \multicolumn{2}{|c|}{ Терміни } & \multirow{2}{*}{$\begin{array}{c}\text { I } \\
\text { до згодовування }\end{array}$} & \multirow{3}{*}{$\begin{array}{c}\text { II } \\
14 \text { діб згодовування } \\
37,8 \pm 1,6\end{array}$} & \multirow{3}{*}{$\begin{array}{c}\text { III } \\
28 \text { діб згодовування } \\
36,8 \pm 1,5\end{array}$} & \multirow{3}{*}{$\begin{array}{c}\text { IV } \\
14 \text { діб після припи- } \\
\text { нення згодовування } \\
37,5 \pm 1,5\end{array}$} \\
\hline Групи & & & & & \\
\hline контроль & $\mathrm{H}$ & $34,4 \pm 1,4$ & & & \\
\hline & $\mathrm{C}$ & $49,4 \pm 2,2$ & $44,1 \pm 2,3$ & $45,1 \pm 2,5$ & $47,5 \pm 2,4$ \\
\hline & $\mathrm{B}$ & $16,2 \pm 0,9$ & $18,1 \pm 0,8$ & $18,1 \pm 1,3$ & $16,0 \pm 1,1$ \\
\hline I дослід & $\mathrm{H}$ & $34,3 \pm 1,5$ & $39,2 \pm 1,7^{*}$ & $41,3 \pm 2,0 *$ & $41,1 \pm 2,1^{*}$ \\
\hline \multirow[t]{2}{*}{ ПБ } & $\mathrm{C}$ & $51,3 \pm 2,2$ & $46,1 \pm 2,0$ & $46,5 \pm 2,1$ & $45,3 \pm 2,5$ \\
\hline & $\mathrm{B}$ & $15,4 \pm 0,9$ & $14,7 \pm 0,8$ & $12,2 \pm 0,8^{*}$ & $13,6 \pm 0,9$ \\
\hline II дослід ПБ + & $\mathrm{H}$ & $36,2 \pm 1,5$ & $38,4 \pm 1,4$ & $41,4 \pm 1,9^{*}$ & $40,3 \pm 1,8$ \\
\hline $\mathrm{CoCl}_{2}$ у дозі & $\mathrm{C}$ & $50,1 \pm 2,2$ & $49,5 \pm 2,3$ & $47,6 \pm 2,0$ & $48,1 \pm 2,1$ \\
\hline $0,08 \mathrm{м} \Gamma / к \Gamma$ & $\mathrm{B}$ & $13,7 \pm 0,9$ & $12,1 \pm 0,8$ & $11,0 \pm 0,7^{*}$ & $11,6 \pm 0,8$ \\
\hline III дослід & $\mathrm{H}$ & $32,3 \pm 1,5$ & $39,9 \pm 1,6^{* *}$ & $45,0 \pm 2,3^{* * *}$ & $47,0 \pm 2,5 * * *$ \\
\hline ПБ + НчСо у & $\mathrm{C}$ & $51,6 \pm 2,4$ & $50,1 \pm 2,3$ & $49,4 \pm 2,4$ & $43,2 \pm 2,1^{*}$ \\
\hline дозі 0,08 мг/кг & B & $16,1 \pm 1,3$ & $10,0 \pm 1,0 * * *$ & $5,6 \pm 0,8 * * *$ & $9,8 \pm 0,9 * * *$ \\
\hline IV дослід & $\mathrm{H}$ & $34,1 \pm 1,5$ & $38,0 \pm 1,7$ & $38,3 \pm 1,9$ & $38,7 \pm 1,9$ \\
\hline ПБ + НчСо у & $\mathrm{C}$ & $51,1 \pm 2,5$ & $48,5 \pm 2,3$ & $50,3 \pm 2,4$ & $51,3 \pm 2,0$ \\
\hline дозі 0,8 мг/кг & $\mathrm{B}$ & $14,8 \pm 0,9$ & $13,5 \pm 0,9$ & $11,4 \pm 1,0 *$ & $10,0 \pm 0,9 * * *$ \\
\hline
\end{tabular}

\section{Таблиця 3}

Здатність Streptococcus spp., виділених із вмісту сліпої кишки курей-несучок, до формування біоплівки різної щільності за умов впливу добавок Кобальту та Пробіотика у динаміці 42 діб (\%, n = 10)

\begin{tabular}{lcccc}
\hline \multicolumn{2}{c}{ Терміни } & I & II & III \\
Групи & & до згодовування & IV діб згодовування & 28 діб згодовування \\
\hline контроль & $\mathrm{H}$ & $30,2 \pm 1,4$ & $32,1 \pm 1,3$ & $33,1 \pm 1,4$ \\
& $\mathrm{C}$ & $35,5 \pm 1,5$ & $37,4 \pm 1,6$ & $35,1 \pm 1,4$ \\
нення згодовування
\end{tabular}


Що стосується мікроорганізмів Streptococcus spp. (табл. 3), то найбільш виражену дію можна було спостерігати у III досліді при застосуванні пробіотика в комплексі з нанокобальтом у дозі 0,08 мг/кг, а саме: на $17,4 \%$ зменшилась кількість мікроорганізмів 3 високою біоплівкоутворюючою здатністю з поступовим збільшенням відсотка таких, що мали низьку (на $10,2 \%$ ) та середню (на 7,2\%) біоплівкоутворюючу здатність. Після припинення застосування добавки на 14 день встановлені зміни співвідношення зберігались.

При використанні добавки $\mathrm{CoCl}_{2}$ (II дослід) не встановлювались зміни у рівні середньобіоплівкоутворюючих мікроорганізмів, а зміни у співвідношенні досліджуваних мікроорганізмів з високою і низькою біоплівкоутворюючою здатністю були менш виражеHi.

Подібну динаміку співвідношення мікроорганізмів Streptococcus spp. спостерігали і при використанні як добавки самого пробіотика, і пробіотика разом 3 вищою дозою нанокобальту $(0,8$ мг/кг)

\section{Висновки}

Використання пробіотичних мікроорганізмів роду Lactobacillus в комплексі з препаратами нанокобальту у дозі 0,08 мг/кг живої ваги в годівлі курей-несучок обумовило найбільш суттєве вірогідне зменшення частки кокових форм мікрофлори сліпих кишок (Staphylococcus spp., Enterococcus spp., Streptococcus spp.), що утворювали біоплівки високої щільності за рахунок збільшення відсотка цих мікроорганізмів 3 низькою та середньою біоплівкоутворюючою здатністю.

Перспективи подальших досліджень. В подальшому планується встановити закономірності інтенсивності біоплівкоутворюючої здатності мікрофлори кишечнику курей-несучок в умовах досліду, зокрема iї якісну сторону.

\section{References}

Pavlova, N.V., Kirzaev, F.S., \& Lapinskajte, P. (2006). The value of intestinal normal microflora of birds for their organism. H. zootech. 10, 37-40.

Scupham, A.J. (2007). Succession in the intestinal microbiota of preadolescent turkeys. FEMS Microbiology Ecology. 60(1), 136-147. doi: 10.1111/j.15746941.2006.00245.x

Vecherskii, M.V., Kuznetsova, T.A., Kostina, N.A., Gorlenko, M.V., Golichenkov, M.B., Umarov, M.M., \&
Naumova, E.I. (2014). Role of microbiocenosis of the gastrointestinal tract in the nutrition of grouse. Biology Bulletin. 41(3), 281-285. doi: 10.1134/S1062359014030108.

Round, J.L., \& Mazmanian, S.K. (2009). The gut microbiota shapes intestinal immune responses during health and disease. Nat Rev Immunol. 9(5), 313-323. doi: 10.1038/nri2515.

Lukovs'ka, O.I. (2015). Mikrobotsenoz kyshechnyku perepeliv porody «Faraon» za vykorystannya preparativ «Activo» $\mathrm{i}$ «Propoul». Biolohiya tvaryn. 17(4), 181 (in Ukrainian).

Scupham, A.J. (2009). Campylobacter colonization of the Turkey intestine in the context of microbial community development. Appl. Environ. Microbiol. 75(11), 3564-3571. doi:10.1128/AEM.01409-08.

Lee, Y.K., \& Mazmanian, S.K. (2010). Has the microbiota played a critical role in the evolution of the adaptive immune system? Science. 330(6012), 1768-1773. doi: 10.1126/science.1195568.

Stanley, D., Hughes, R.J., \& Moore, R.J. (2014). Microbiota of the chicken gastrointestinal tract: influence on health, productivity and disease. Appl. Microbiol. Biotechnol. 98(10), 4301-4309. doi: 10.1007/s00253014-5646-2.

Mohd Shaufi, M.A., Sieo, C.C., Chong, C.W., Gan, H.M., \& Ho, Y.W. (2015). Deciphering chicken gut microbial dynamics based on high-throughput 16S rRNA metagenomics analyses. Gut Pathogens. 7, 4. doi: 10.1186/s13099-015-0051-7.

Dibner, J.J., Richards, J.D., \& Knight, C.D. (2008). Microbial imprinting in gut development and health. J Appl Poult Res. 17(1), 174-188. doi: 10.3382/japr.2007-00100.

Kamins'ka, M.V., Stefanyshyn, O.M., Hural', S.V., Popyk, I.M., Ponkalo, L.I., \& Borets'ka, N.I. (2015). Osoblyvosti formuvannya mikrobotsenozu kyshkovyka pekins'kykh broylernykh kachok. Sil's'kohospodars'ka mikrobiolohiya. 21, 72-76 (in Ukrainian).

Baldi, F., Bianco, M.A., Nardone, G., Pilotto, A., \& Zamparo, E. (2009). Focus on acute diarrhoeal disease. World J. Gastroenterol. 15(27), 3341-3348. doi: $10.3748 /$ wjg. 15.3341 .

Kukhtyn, M., Berhilevych, O., Kravcheniuk, K., Shynkaruk, O., Horiuk, Y., \& Semaniuk, N. (2017). The influence of disinfectants on microbial biofilms of dairy equipment. EUREKA: Life Sciences. 5, 11-17. doi: 10.21303/2504-5695.2017.00423. 